\title{
Quality of Life and Depressive Symptoms in Parkinson's Disease After Subthalamic Deep Brain Stimulation: A 2-Year Follow-Up Study
}

\author{
Subtalamik Derin Beyin Stimülasyonundan sonra Parkinson \\ Hastalı̆̆ında Yaşam Kalitesi ve Depresif Belirtiler: 2 Yıllık Takip \\ Çalışması
}

Tomasz TYKOCKI ${ }^{1}$, Krzysztof SZALECKI ${ }^{1}$, Henryk KOZIARA ${ }^{2}$, Paweł NAUMAN ${ }^{1}$, Tomasz MANDAT ${ }^{2}$

${ }_{1}^{1}$ Institute Psychiatry and Neurology, Department of Neurosurgery, Warsaw, Poland

${ }_{2}^{2}$ Institute of Oncology in Warsaw, Department of Neurosurgery, Warsaw, Poland

Corresponding Author: Tomasz TYKOCKI / E-mail: ttomasz@mp.pl

\begin{abstract}
AIM: To assess the correlation between quality of life (QoL), depressive symptoms and motor signs in patients with Parkinson disease after subthalamic deep brain stimulation (DBS STN).

MATERIAL and METHODS: 74 patients, average age $55.6 \pm 7$ and duration of disease 12.3 years \pm 3.8 , treated with I STN DBS for PD were included in the study. All patients were evaluated with (UPDRS III), (PDQ-39) (BDI) at baseline and at 6, 12, and 24-month follow up. All patients were also stratified into three groups depending on UPDRS III improvement $(<30 \%, 30-60 \%,>60 \%)$.

RESULTS: Scores in all scales significantly decreased from baseline. The improvement in PDQ-39 was 43.3\%, in BDI $25.3 \%$; UPDRS-III 55.5\% at 6 months. At 24 months, motor results and QoL deteriorated by $15.6 \%$ and $19.6 \%$ respectively. BDI remained unchanged. Mean scores at baseline in PDQ-39 were group I $67.4 \pm 29.7$; II 64.8 232.0 ; III 53.4 \pm 22.0 and for BDI, group I 17.4 \pm 12.04 ; II 14.0 \pm 9.7 ; III- 15.1 \pm 10.55 . Scores decreased significantly with DBS at 6-month follow-up and mean change was: PDQ-39, group I 42.7\%, II- 40.7\%, III 51.6\%; BDI group I 23\%, II $28.1 \%$, III $23.3 \%$.
\end{abstract}

CONCLUSION: Reduction of depressive symptoms, motor signs and improvement of QoL in PD after DBS STN are closely related. Improvement of QoL depends significantly on motor symptoms.

KEYWORDS: Prakinson's disesase, Quality of life, Depression, Motor signs

öz

AMAÇ: Subtalamik derin beyin stimülasyonundan (DBS STN) sonra Parkinson hastalarında yaşam kalitesi (QoL) depresif belirtiler ve motor bulgular arasında korelasyonu değerlendirmek.

YÖNTEM ve GEREÇLER: Ortalama yaşı 55,6 \pm 7 ve hastalık süresi 12,3 yıl $\pm 3,8$ olan ve PD STN DBS ile tedavi edilen 74 hasta çalışmaya dahil edildi. Tüm hastalar başlangıçta ve 6, 12 ve 24 aylık takipte (UPDRS III), (PDQ-39) (BDI) ile değerlendirildi. Tüm hastalar ayrıca UPDRS III'teki düzelmeye göre üç gruba katmanlandırıldı (<\%30, \%30-60, >\%60).

BULGULAR: Tüm ölçeklerdeki puanlar başlangıca göre önemli ölçüde azaldı. PDQ-39'daki iyileşme 6 ayda \%43,3 BDI'da \%25,3 ; UPDRS-III \%55,5 bulundu. 24 ayda motor sonuçlar QoL sırasıyla \%15,6 ve \%19,6 bozuldu. BDI değişmeden kaldı. PDQ-39 için başlangıçtaki ortalama

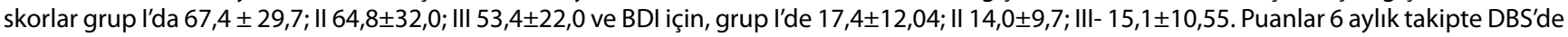
önemli ölçüde azaldı ve ortalama değişim şöyleydi: PDQ-39, grup I \%42,7, II- \%40,7, III \%51,6; BDI grup I \%23, II \%28,1, III \%23,3.

SONUÇ: DBS STN sonrasında PD'de depresif belirtiler, motor bulgularda azalma ve QoL'de artış yakından ilişkilidir. QoL artışı önemli ölçüde motor belirtilere bağlıdır.

ANAHTAR SÖZCÜKLER: Parkinson hastalığı, Yaşam kalitesi, Depresyon, Motor bulgular 


\section{INTRODUCTION}

The prevalence of depression in Parkinson's disease (PD) is estimated to be $45 \%$ (3) and major depression $17 \%$ (18). In The Study of Antidepressants in Parkinson's Disease among PD patients with the optimal antiparkinsonian treatment remission criteria were met in $44-37 \%$ and there was a $\geq 50 \%$ response in $68-53 \%$ of patients (19). Depressive symptoms may worsen in OFF medication state and optimal control of motor fluctuations is associated with mood elevating effect (17). Therefore, deep brain stimulation (DBS), which is a standard neurosurgical approach for PD, is not only of high therapeutic value in the treatment of cardinal motor signs in PD but also ameliorates depressive symptoms and quality of life (QoL). The direct antidepressive mechanism is probably associated with the impact of DBS on the medial forebrain bundle and the stimulation of the limbic system, and indirectly resulting from the improvement of motor functions (12).

There are only a few studies in the literature relating to the assessment of QoL and depressive symptoms in PD in longterm follow-up after STN DBS. Based on some of these results, an assumption on the correlated between the improvement in motor symptoms and QoL could be found. Therefore, the authors of this study have proposed the evaluation of the QoL and depressive symptoms according to the degree of improvement in motor symptoms after the stimulation. The study was designed to compare whether there are any differences in QoL between groups with different motor response after DBS. Additionally, a special consideration was given to investigate the relationship between $\mathrm{QoL}$, depressive symptoms and motor signs.

\section{MATERIAL and METHODS}

74 patients (38 men and 36 women) were treated with bilateral subthalamic (STN) DBS for PD between 2008-2010. The average age at surgery was $55.6 \pm 7$ years and the duration of the disease 12.3 years \pm 3.8 . All participants were qualified for the subthalamic deep brain stimulation according to the CAPSIT-PD criteria (5). Preoperatively, all patients were evaluated with Unified Parkinson's Disease Rating Scale part III (UPDRS-III), in ON=26.9 \pm 11 and OFF $=51.3 \pm 14$. The mean levodopa daily dose (LDD) was $1195.3 \pm 392 \mathrm{mg}$ and mean improvement after pharmacological treatment before the operation, calculated as (OFF-ON/OFF) was $48 \%$. 39 of 74 (52.7\%) patients were on antidepressant drugs preoperatively: tetracyclic antidepressants (TCAs) $(n=8)$, selective serotonin reuptake inhibitors (SSRIs) $(n=20)$, serotonin-norepinephrine reuptake inhibitors (SNRIs) $(n=4)$, noradrenergic and specific serotonergic antidepressant ( $\mathrm{NaSSA})(\mathrm{n}=7) .42 / 74$ were taking dopamine agonists together with L-Dopa - pramipexole $(n=18)$; ropinirole $(n=16)$ and amantadine $(n=8)$.

Details of the procedure were described previously (14). The stimulation was initiated after 4 weeks. The quality of life was evaluated with the 39-item Parkinson's disease questionnaire (PDQ-39) and depressive symptoms with Beck's depression inventory (BDI). All the assessments were taken at baseline with no stimulation and at 6, 12 and 24-month follow-up with active DBS, additionally results were reviewed with respect to gender. The improvement from baseline in UPDRS-III with active stimulation was stratified into three groups: I) less than $30 \%$; II) $30-60 \%$ and III) more than $60 \%$ in OFF medication state. The improvement level after initiation of the stimulation in PDQ-39 and BDI was compared with respect to stratified groups.

All data are reported as means \pm standard deviation. Means were compared using ANOVA for repeated measurements and followed by post-hoc testing with a Scheffe test for multiple comparisons. A value of $\mathrm{P} \leq 0.05$ was considered statistically significant. All the statistical analysis and diagrams were created using Statistica 9 (StatSoft) software.

\section{RESULTS}

Demographic data for the 74 patients are presented in Table I. Completed PDQ-39 and BDI data were available from both pre- and post- operative time periods in all individuals. Mean baseline scores in PDQ-39 and BDI were $64.95 \pm 30.09$ and $14.85 \pm 10.9$ respectively. At subsequent follow-up visits scheduled for 6,12 and 24 postprocedural months with active DBS, results declined in both scales. Scores in PDQ39 significantly decreased at 6-month follow-up to 37.32 \pm 16.53 (difference from baseline 27.62; 43.3\%; $p<0.001$ ), then the results had a slight upward trend to $39.5 \pm 17.54$ and $43.15 \pm 20.54$ at $12^{\text {th }}$ and $24^{\text {th }}$ postoperative month (Table II). The deterioration in the quality of life between 6and 24-month was statistically significant $(15.6 \% ; \mathrm{p}=0.037)$. Improvement in BDI reached $25.3 \%(p<0.001)$ at 6 -month follow-up, the scores remained stable at further control visits.

Table I: Preoperative Characteristic of the Patient Cohort

\begin{tabular}{|l|c|c|c|}
\hline $\mathrm{n}=\mathbf{7 4}$ & Mean & \multicolumn{2}{|c|}{$(95 \% \mathrm{Cl})$} \\
\hline PD duration (years) & $12.3 \pm 3.8$ & 11.4 & 13.2 \\
\hline Age & $55.6 \pm 7,0$ & 54.0 & 57.2 \\
\hline UPDRS-III ON & $26.9 \pm 10.7$ & 24.4 & 29.3 \\
\hline UPDRS-III OFF & $51.3 \pm 13.7$ & 48.1 & 54,5 \\
\hline LDD $(\mathrm{mg})$ & $1195.3 \pm 392.1$ & 1104.4 & 1286.1 \\
\hline
\end{tabular}

PD - Parkinson's disease; UPDRS - Unified Parkinson's Disease Rating Scale; $\mathbf{O N}$ - on medication state; OFF - off medication state; LDD - levodopa daily dose.

Table II: Results of the 39-item Parkinson's Disease Questionnaire and the Beck Depression Inventory at Baseline and Follow-up Visits

\begin{tabular}{|l|c|c|c|}
\hline Baseline & PDQ -39 & BDI & UPDRS-III \\
\hline 6 months & $+37.95 \pm 30.09$ & $14.85 \pm 10.9$ & $51.3 \pm 13.7$ \\
\hline 12 months & $39.51 \pm 17.54$ & $11.39 \pm 9.36$ & $22.7 \pm 9.4$ \\
\hline 24 months & $\neq 43.15 \pm 20.54$ & $11.35 \pm 9.71$ & $\neq 27.4 \pm 9.3$ \\
\hline
\end{tabular}

t change from baseline; $p<0.05$

\# change between 6 and 24 months; $p<0.05$. 
There was a notable change in motor outcomes of $55.5 \%$ (28.5; $\mathrm{p}<0.005)$ at 6 month, but between 12 and 24 months scores in UPDRS-III significantly increased (19.6\%) (Figure 1). When all participants were stratified into 3 groups according to the improvement in OFF medication UPDRS mean scores at baseline in PDQ-39 were as follows, group I 67.4 \pm 29.7; group II $64.8 \pm 32.0$; Group III 53.4 \pm 22.0 and in BDI, I 17.4 \pm 10.5 ; II $14.0 \pm 9.7$; III 15.1 \pm 12.0 (Table III). The differences at baseline were significant only between group I and II compared with group III in PDQ-39 but not between any results in BDI. All the scores decreased significantly with active stimulation at 6-month follow-up and mean change in the relevant groups was: PDQ-39, group I-42.7\%, 28.79 pts; II- 40.7\%, 26.43 pts; III$51.6 \%, 27.57$ pts (Figure 2); BDI group I-23\%, 4.0 pts; II-28.1\%, 3.94 pts; II-23.3\%, 3.53 pts (Figure 3).

At further follow up (12 and 24 months) scores in PDQ-39 had an upward trend and between 6 and 24 months changed by $24.1 \%$ in group I, $38.7 \%$ III and $4.5 \%$ II. The results in BDI were almost unaffected with time. There were no statistical discrepancies between genders at any follow-up scores in both scales. However, there has been a trend of slightly higher $\mathrm{BDI}$ results in females (Table IV).

\section{DISCUSSION}

Complex symptomatology of Parkinson's diseases, including motor and non-motor features, has a significantly negative impact on patients' quality of life (9). Studies show motor signs and depression as the strongest predictors of QoL in PD (26). Other factors affecting QoL are fatigue, anxiety and side effects of dopaminergic drugs $(1,8)$. Based on fact that motor symptoms have a major influence on QoL we decided to stratify patients into groups depending on motor signs reduction. The grouped analysis provided a reliable and persuasive comparison of QoL and depression between comparably-matched patients for results in UPDRS-III.

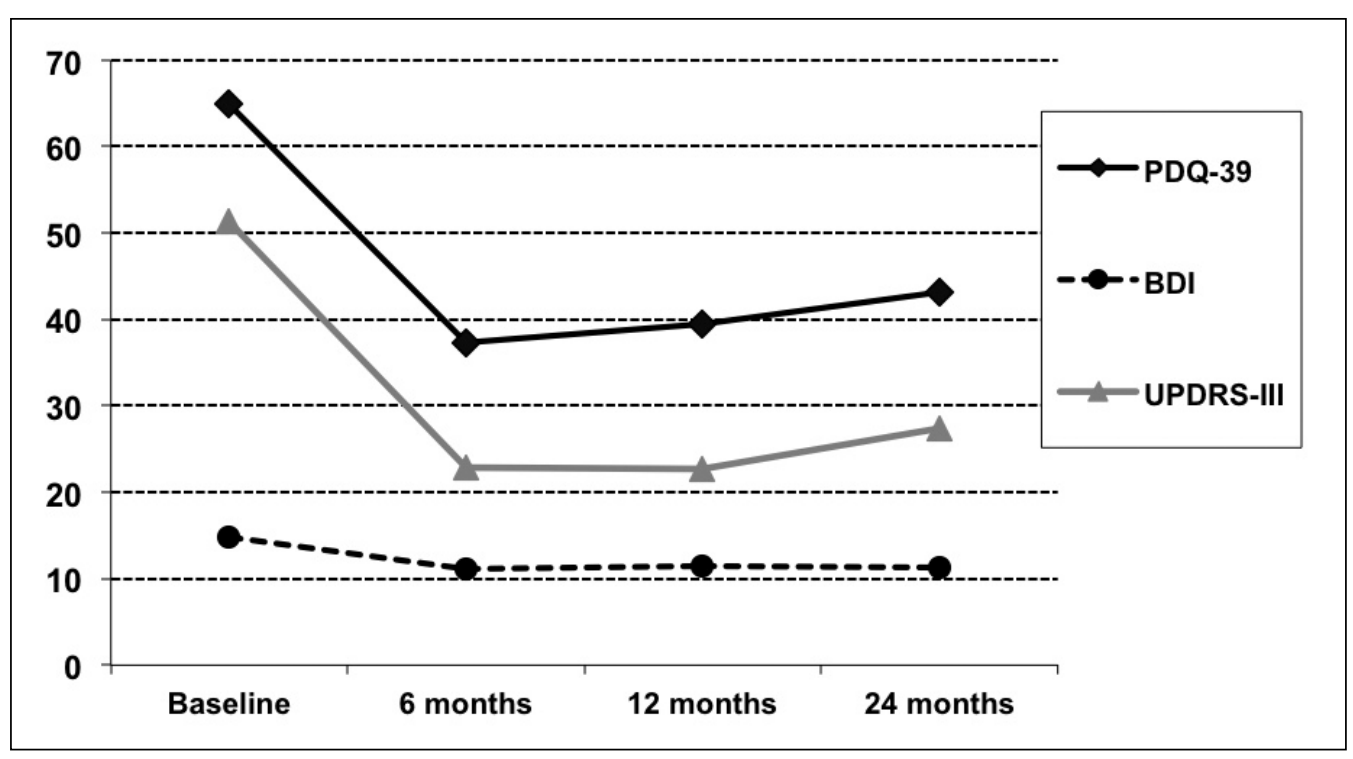

Figure 1: Change in 39item Parkinson's Disease Questionnaire, Beck Depression Inventory and Unified Parkinson's Disease Rating Scale part III.

Table III: Results in the 39-item Parkinson's Disease Questionnaire, the Beck Depression Inventory, Age and Parkinson's Disease Duration for UPDRS Improvement Stratified Groups at Baseline and 6-, 12- and 24-month Follow-up

\begin{tabular}{|c|c|c|c|c|c|c|c|c|c|c|c|}
\hline \multirow[b]{2}{*}{$\begin{array}{l}\text { UPDRS } \\
\text { improvement }\end{array}$} & \multirow[b]{2}{*}{$n$} & \multicolumn{4}{|c|}{ PDQ-39 } & \multicolumn{4}{|c|}{ BDI } & \multirow{2}{*}{$\begin{array}{c}\text { Age } \\
\text { (years) }\end{array}$} & \multirow{2}{*}{$\begin{array}{c}\text { PD } \\
\text { Duration } \\
\text { (years) } \\
\end{array}$} \\
\hline & & Baseline & $\begin{array}{l}6 \\
\text { months }\end{array}$ & $\begin{array}{l}12 \\
\text { months }\end{array}$ & $\begin{array}{l}24 \\
\text { months }\end{array}$ & Baseline & $\begin{array}{l}6 \\
\text { months }\end{array}$ & $\begin{array}{l}12 \\
\text { months }\end{array}$ & $\begin{array}{l}24 \\
\text { months }\end{array}$ & & \\
\hline$<30 \%$ & 29 & $\begin{array}{l}67.41 \pm \\
29.75\end{array}$ & $\begin{array}{l}\dagger 38.62 \pm \\
15.36\end{array}$ & $\begin{array}{l}+41.18 \\
\pm 16.17\end{array}$ & \begin{tabular}{|l|}
$\neq 47.93 \pm$ \\
24.88
\end{tabular} & $\begin{array}{l}17.43 \pm \\
12.04\end{array}$ & $\begin{array}{l}+13.43 \pm \\
9.29\end{array}$ & $\begin{array}{l}\dagger 12.86 \pm \\
8.78\end{array}$ & $\begin{array}{l}11.29 \pm \\
6.8\end{array}$ & $\begin{array}{l}54.94 \pm \\
7.12\end{array}$ & $\begin{array}{l}11.29 \pm \\
4.23\end{array}$ \\
\hline $30-60 \%$ & 24 & $\begin{array}{l}64.85 \pm \\
32.04\end{array}$ & $\begin{array}{l}+38.42 \pm \\
17.80\end{array}$ & $\begin{array}{l}+40.21 \pm \\
18.8\end{array}$ & $\begin{array}{l}40.15 \pm \\
15.52\end{array}$ & $\begin{array}{l}14.03 \pm \\
9.67\end{array}$ & $\begin{array}{l}+10.09 \pm \\
7.24\end{array}$ & $\begin{array}{l}+10.24 \pm \\
7.08\end{array}$ & $\begin{array}{l}10.27 \pm \\
7.25\end{array}$ & $\begin{array}{l}56.21 \pm \\
7.13\end{array}$ & $\begin{array}{l}12.12 \pm \\
3.35\end{array}$ \\
\hline$>60 \%$ & 21 & $\begin{array}{l}53.43 \pm \\
21.99\end{array}$ & $\begin{array}{l}+25.86 \\
\pm 12.90 \\
28.14 \\
\pm 15.79\end{array}$ & $\begin{array}{l}\neq 35.86 \pm \\
16.05\end{array}$ & $\begin{array}{l}15.12 \pm \\
12.04\end{array}$ & $\begin{array}{l}+15.12 \pm \\
10.55\end{array}$ & $\begin{array}{l}+11.59 \pm \\
10.40\end{array}$ & $\begin{array}{l}12.21 \pm \\
11.34\end{array}$ & $\begin{array}{l}12.41 \pm \\
12.12\end{array}$ & $\begin{array}{l}56.14 \pm \\
5.9\end{array}$ & $\begin{array}{l}12.62 \pm \\
4.11\end{array}$ \\
\hline
\end{tabular}


Table IV: Results of the 39-item Parkinson's Disease Questionnaire and the Beck Depression Inventory for Gender at Baseline and Follow-up Visits

\begin{tabular}{|l|c|c|c|c|}
\multirow{2}{*}{ Baseline } & \multicolumn{2}{|c|}{ PDQ-39 } & Male & BDI \\
\cline { 2 - 5 } & Male & Female & $13.76 \pm 10.12$ & $16.00 \pm 11.51$ \\
\hline 6 months & $66.11 \pm 30.92$ & $63.72 \pm 29.57$ & $9.61 \pm 8.47$ & $12.67 \pm 9.28$ \\
\hline 12 months & $36.74 \pm 15.08$ & $37.94 \pm 18.13$ & $10.00 \pm 8.84$ & $12.86 \pm 9.78$ \\
\hline 24 months & $39.34 \pm 16.25$ & $39.69 \pm 19.03$ & $10.00 \pm 9.35$ & $12.78 \pm 10.01$ \\
\hline
\end{tabular}
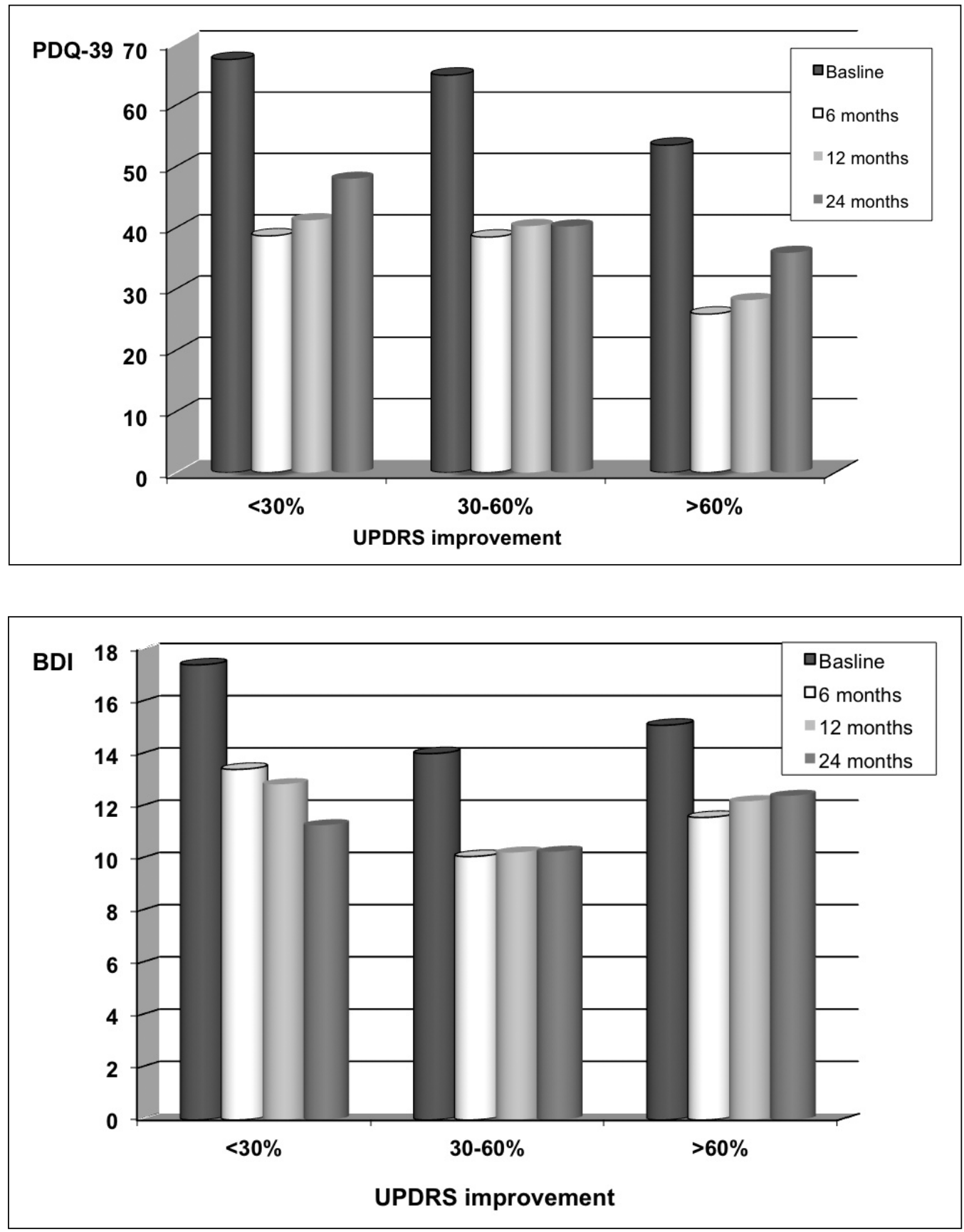

Figure 2: Results in 39item Parkinson's Disease Questionnaire for stratified groups.
Figure 3: Results in Beck Depression Inventory for stratified groups. 
Our results extend those of previous studies in which similar improvements in QoL have been shown, as measured using PDQ-39 after STN DBS. In two randomized trials comparing bilateral STN DBS with best medical therapy at 6-month follow-up, results correspond to an improvement of $17 \%$ and $25 \%$ in both DBS series, with almost no change in the medication groups $(23,24)$. In other studies improvement of up to $68 \%$ has been reported in PDQ-39 at up to 24 months of follow up $(13,21,11,20)$. Interestingly, an improvement in QoL in pallidal and subthalamic DBS after 2 years in a randomized trial was only moderate and reached $11.2 \%$ and $8.9 \%$ respectively (7). In the study of Lyons at al. improvement degree in PDQ-39 changed from $32.2 \%$ to $20.6 \%$ between year one and two of follow-up. Weaver et al. reported results of DBS for two targets GPi and STN in 36-month follow up. The improvement in PDQ-39 was similar for both targets at 6 months (25\%-GPi and 27\%-STN) but diminished over time to $8 \%$ in both groups (25).

These findings are consistent with the observation from this study (13). They also found significant positive correlations between motor outcomes and QoL with the strongest predictor of bradykinesia. Rigidity was not correlated with any aspect of QoL. According to Daniels at al. cumulative daily off time is the strongest predictor for improvement in QoL after DBS (5).

Ferrera et al. evaluated QoL with Questions on Life Satisfaction (QLSM) questionnaire consisting from 4 modules: General life (A), General health (G), Movement disorders (MD) and Deep brain stimulation (DBS) (6). Results showed significant amelioration in QLSM-G part referring to energy 'level/ enjoyment of life' and disability and QLSM-MD assessing controllability/fluidity of movement, stability, hand dexterity, undisturbed sleep, swallowing, bladder/ intestinal function and cognition. The improvement did not extend to the QLSM-A evaluating occupational function, interpersonal relationships, leisure activities and living conditions. On the QLSM-DBS, patients reported high satisfaction regarding stimulator side effects and conspicuousness. The abovementioned results demonstrate the important impact of non-motor symptoms on the QoL in patients with PD. This hypothesis could be strengthened by the results of Lee et al. who found that socioeconomic, cognitive and emotional factors play a more prominent role in overall quality of life compared with motor dysfunction (10).

Based on the results from large series of patients, the improvement in BDI may vary between 15.8-32.6\%, demonstrating only moderate impact of neuromodulation on depression (25,2). A positive correlation was found between QoL and the improvement in depression but not in motor results (22). The emotional status of PD patients might be changed after STN DBS. Anxiety tends to improve significantly at the initial period of stimulation but after 3 months may get worse, correlating with the increase of voltage and pulse-width of the stimulation (4). An interesting finding is the occurrence of impulse control disorders and dopamine dysregulation syndrome among some PD patients following DBS surgery (16).

Our results showed marked primary improvement in all scales, BDI, UPDRS-III and PDQ-39 after STN DBS. However, at further observations only the assessment of depressive symptoms remained at the same level, and QoL and motor symptoms worsened. Thus one can assume that the change in QoL is mostly correlated with the severity of motor signs, but certainly equally dependent on non-motor factors, which have not been tested in this study. Another major finding of this study is the most significant improvement in quality of life among patients with the best reduction of motor symptoms after DBS (more than 60\% in UPDRS-III).

This study has several limitations. First, the use of self-report questionnaires of depression (BDI) and quality of life (PDQ39), although practical, does not allow to clarify the nature and severity of depression and life standards. As the term QoL includes physical, functional, social, cultural context and emotional well-being of patients, many of these variables could not be objectively evaluated with standard questionnaires including PDQ-39. Second, both the evaluators and patients were not blinded as to whether the stimulation was switched ON or OFF. Third, application of patients' diaries could allow for a more detailed, daily evaluation of parkinsonian symptoms and everyday difficulties caused by the disease.

\section{CONCLUSIONS}

This study reveals the significant reduction of depressive symptoms, motor signs and improvement of the quality of life in patients with PD after DBS STN. Motor disability was proven to be a dominant predictor of QoL. At longer followup, a significant downward trend of QoL and motor outcomes was noticed, whereas depressive symptoms remained unchanged.

\section{DISCLOSURE}

The authors have no personal financial or institutional interest in any of the drugs, materials, or devices described in this article.

\section{REFERENCES}

1. Barone $P$, Antonini A, Colosimo C, Marconi R, Morgante $L$, Avarello TP, Bottacchi E, Cannas A, Ceravolo G, Ceravolo R, Cicarelli G, Gaglio RM, Giglia RM, lemolo F, Manfredi M, Meco G, Nicoletti A, Pederzoli M, Petrone A, Pisani A, Pontieri FE, Quatrale R, Ramat S, Scala R, Volpe G, Zappulla S, Bentivoglio AR, Stocchi F, Trianni G, Dotto PD: The PRIAMO study: A multicenter assessment of nonmotor symptoms and their impact on quality of life in Parkinson's disease. Mov Disord 24(11):1641-1649, 2009

2. Burdick AP, Foote KD, Wu S, Bowers $D$, Zeilman $P$, Jacobson $C E$, Ward HE, Okun MS: Do patient's get angrier following STN, GPi, and thalamic deep brain stimulation. Neuroimage 54:S227-232, 2011

3. Burn DJ: Beyond the iron mask: Towards better recognition and treatment of depression associated with Parkinson's disease. Mov Disord 17: 445-454, 2002 
4. Chang C, Li N, Wu Y, Geng N, Ge S, Wang J, Wang X, Wang X: Associations between bilateral subthalamic nucleus deep brain stimulation (STN-DBS) and anxiety in Parkinson's Disease patients: A controlled study. J Neuropsychiatry Clin Neurosci 24(3):316-325, 2012

5. Daniels $C$, Krack P, Volkmann J, Raethjen J, Pinsker MO, Kloss M, Tronnier V, Schnitzler A, Wojtecki L, Bötzel K, Danek A, Hilker R, Sturm V, Kupsch A, Karner E, Deuschl G, Witt K: Is improvement in the quality of life after subthalamic nucleus stimulation in Parkinson's disease predictable? Mov Disord 26(14):2516-2521, 2011

6. Defer $G L$, Widner $H$, Marié RM, Rémy $P$, Levivier $M$ : Core assessment program for surgical interventional therapies in Parkinson's disease (CAPSIT-PD). Mov Disord 14(4):572-584, 1999

7. Ferrara J, Diamond A, Hunter C, Davidson A, Almaguer M, Jankovic J: Impact of STN-DBS on life and health satisfaction in patients with Parkinson's disease. J Neurol Neurosurg Psychiatry 81(3):315-359, 2010

8. Follett KA, Weaver FM, Stern $M$, Hur $K$, Harris $C L$, Luo $P$, Marks WJ Jr, Rothlind J, Sagher O, Moy C, Pahwa R, Burchiel K, Hogarth P, Lai EC, Duda JE, Holloway K, Samii A, Horn S, Bronstein JM, Stoner G, Starr PA, Simpson R, Baltuch G, De Salles A, Huang GD, Reda DJ: CSP 468 Study Group. Pallidal versus subthalamic deep-brain stimulation for Parkinson's disease. N Engl J Med 362(22):2077-2091, 2010

9. Gómez-Esteban JC, Zarranz JJ, Lezcano E, Tijero B, Luna A, Velasco F, Rouco I, Garamendi I: Influence of motor symptoms upon the quality of life of patients with Parkinson's disease. Eur Neurol 57(3):161-165, 2007

10. Hristova DR, Hristov JI, Mateva NG, Papathanasiou JV: Quality of life in patients with Parkinson's disease. Folia Med (Plovdiv) 51(4):58-64, 2009

11. Lee MA, Walker RW, Hildreth AJ, Prentice WM: Individualized assessment of quality of life in idiopathic Parkinson's disease. Mov Disord 21(11):1929-1934, 2006

12. Lezcano E, Gómez-Esteban JC, Zarranz JJ, Lambarri I, Madoz P, Bilbao G, Pomposo I, Garibi J: Improvement in quality of life in patients with advanced Parkinson's disease following bilateral deep-brain stimulation in subthalamic nucleus. Eur J Neurol 11(7):451-454, 2004

13. Lim SY, O'Sullivan SS, Kotschet K, Gallagher DA, Lacey C, Lawrence AD, Lees AJ, O'Sullivan DJ, Peppard RF, Rodrigues JP, Schrag A, Silberstein P, Tisch S, Evans AH: Dopamine dysregulation syndrome, impulse control disorders and punding after deep brain stimulation surgery for Parkinson's disease. J Clin Neurosci 16:1148-1152, 2009

14. Lyons KE, Pahwa R: Long-term benefits in quality of life provided by bilateral subthalamic stimulation in patients with Parkinson disease. J Neurosurg103(2):252-255, 2005

15. Mandat T, Tykocki T, Koziara H, Koziorowski D, Brodacki B, Rola R, Bonicki W, Nauman P: Subthalamic deep brain stimulation for the treatment of Parkinson disease. Neurol Neurochir Pol 45(1):32-36, 2011

16. Martínez-Martín P, Valldeoriola F, Tolosa E, Pilleri M, Molinuevo $J \mathrm{~L}$, Rumià J, Ferrer E: Bilateral subthalamic nucleus stimulation and quality of life in advanced Parkinson's disease. Mov Disord; 17:372-377, 2002

17. Moum SJ, Price CC, Limotai N, Oyama G, Ward H, Jacobson C, Foote KD, Okun MS: Effects of STN and GPi deep brain stimulation on impulse control disorders and dopamine dysregulation syndrome. PLoS One 7(1):e29768, 2012
18. Piccinni A, Marazziti D, Veltri A, Ceravolo $R$, Ramacciotti C, Carlini M, Del Debbioa A, Schiavia E, Bonuccellib U, Dell'Ossoa L: Depressive symptoms in Parkinson's disease. Compr Psychiatry 2011 dx.doi.org/10.1016/j. comppsych.2011.11.002.

19. Reijnders JS, Ehrt U, Weber WE, Aarsland D, Leentjens AF: A systematic review of prevalence studies of depression in Parkinson's disease. Mov Disord 23(2):183-189, 2008

20. Richard IH, McDermott MP, Kurlan R, Lyness JM, Como PG, Pearson N, Factor SA, Juncos J, Serrano Ramos C, Brodsky M, Manning C, Marsh L, Shulman L, Fernandez HH, Black KJ, Panisset M, Christine CW, Jiang W, Singer C, Horn S, Pfeiffer R, Rottenberg D, Slevin J, Elmer L, Press D, Hyson HC, McDonald W; SAD-PD Study Group: A randomized, double-blind, placebo-controlled trial of antidepressants in Parkinson disease. Neurology 78:1229-1236, 2012

21. Schüpbach $M$, Gargiulo $M$, Welter $M L$, Mallet $L$, Béhar $C$, Houeto JL, Maltête D, Mesnage V, Agid Y: Neurosurgery in Parkinson disease: A distressed mind in a repaired body? Neurology 66(12):1811-1816, 2006

22. Siderowf A, Jaggi JL, Xie SX, Loveland-Jones $C$, Leng L, Hurtig $H$, Colcher A, Stern M, Chou KL, Liang G, Maccarone H, Simuni $\mathrm{T}$, Baltuch G: Long-term effects of bilateral subthalamic nucleus stimulation on health-related quality of life in advanced Parkinson's disease. Mov Disord 21(6):746-753, 2006

23. Tröster Al, Fields JA, Wilkinson S, Pahwa R, Koller WC, Lyons KE: Effect of motor improvement on quality of life following subthalamic stimulation is mediated by changes in depressive symptomatology. Stereotact Funct Neurosurg 80(1-4):43-47, 2003

24. Weaver FM, Follett K, Stern M, Hur K, Harris C, Marks WJ Jr, Rothlind J, Sagher O, Reda D, Moy CS, Pahwa R, Burchiel K, Hogarth P, Lai EC, Duda JE, Holloway K, Samii A, Horn S, Bronstein J, Stoner G, Heemskerk J, Huang GD; CSP 468 Study Group: Bilateral deep brain stimulation vs best medical therapy for patients with advanced Parkinson disease: $A$ randomized controlled trial. JAMA 301(1):63-73, 2009

25. Weaver FM, Follett KA, Stern M, Luo P, Harris CL, Hur K, Marks WJ Jr, Rothlind J, Sagher O, Moy C, Pahwa R, Burchiel K, Hogarth P, Lai EC, Duda JE, Holloway K, Samii A, Horn S, Bronstein JM, Stoner G, Starr PA, Simpson R, Baltuch G, De Salles A, Huang GD, Reda DJ; CSP 468 Study Group: Randomized trial of deep brain stimulation for Parkinson disease: thirty-six-month outcomes. Neurology 79(1):55-65, 2012

26. Williams A, Gill S, Varma T, Jenkinson C, Quinn N, Mitchell R, Scott R, Ives N, Rick C, Daniels J, Patel S, Wheatley K; PD SURG Collaborative Group: Deep brain stimulation plus best medical therapy versus best medical therapy alone for advanced Parkinson's disease (PD SURG trial): A randomised, open-label trial. Lancet Neurol 9(6):581-591, 2010

27. Witt K, Daniels C, Reiff J, Krack P, Volkmann J, Pinsker MO, Krause M, Tronnier V, Kloss M, Schnitzler A, Wojtecki L, Bötzel K, Danek A, Hilker R, Sturm V, Kupsch A, Karner E, Deuschl G: Neuropsychological and psychiatric changes after deep brain stimulation for Parkinson's disease: A randomised, multicentre study. Lancet Neurol 7(7):605-614, 2008

28. Ziropada L, Stefanova E, Potrebić A, Kostić VS: Quality of life in Serbian patients with Parkinson's disease. Qual Life Res;18(7):833-839, 2009 